\title{
Chapter 31 \\ How Can Urban Design and Architecture Support Spatial Inclusion for Nursing Home Residents?
}

\author{
John Andersen, Annette Bilfeldt, Marianne Mahler, and Lone Sigbrand
}

\subsection{Introduction: Key Concepts of Spatial and Community Exclusion Related to Urban Design and Planning Traditions}

Older persons who experience difficulties related to risks of deteriorating health and lack of mobility (Walker 2010) may face challenges in gaining access to the social life of their residential neighbourhoods. The concept of ageing in place thematises the considerable importance to older people's quality of life that is associated with continued participation in the life in their local area and in the maintenance of connections with neighbourhoods and communities. People may have lived in the same place for their entire lives and may often prefer to remain within the community with which they are most familiar (Wiles 2005; Philips et al. 2010). Ageing in place implies that ageing happens in a specific spatial environment - the familiar environment of one's own home, community and neighbourhood - rather than in an unfamiliar, institutional environment (Moulaert et al. 2018).

While the overwhelming majority of older people in Europe live in domestic settings, it is important not to overlook the role played by institutional settings as places where people may spend their later lives. In this context, nursing home residents should have the possibility to be part of the social life of the cities, communities or neighbourhoods in which they live. Whether or not the nursing home is

\footnotetext{
J. Andersen $(\bowtie)$

Department of People and Technology (IMT), Roskilde Universitet, Roskilde, Denmark e-mail: johna@ruc.dk
}

\author{
A. Bilfeldt \\ University of Greenland, Nuuk, Greenland \\ M. Mahler \\ University of Copenhagen, Copenhagen, Denmark \\ L. Sigbrand \\ Department of the Built Environment, Aalborg University, Aalborg, Denmark
}


situated in the same area that the resident has lived in for years, remaining or becoming part of a neighbourhood and local community when moving to a nursing home is of great importance for individuals' quality of life [also see Villar et al. this volume]. The concept of ageing in place can, therefore, also have meaning for people who move into a nursing home, providing an opportunity to improve their quality of life in an institutional setting in a new neighbourhood. In such situations, the idea of ageing in place can be expanded to encompass the notion of ageing in a new place or of ageing in a new local area.

Against this background, architecture and urban planning policy can play a crucial role for the social inclusion of older persons who reside in nursing homes, not least by ensuring that residents are able to access to their surroundings.

\subsection{The Human Dimension of Urban Design and Planning}

The importance of the human and social dimensions of city planning and development - how urban structures affect community life and social interaction and "liveability" in neighbourhoods - has a long history in urban planning policy and urban movements. This encompasses the iconic work of Jane Jacobs (1961/69), advocacy and empowerment planning in the 1960s (Davidoff 1965), and the work of contemporary communicative and social justice planning theorists like Patsy Healy (2003) and Peter Marcuse (2011). Jan Gehl, the Danish architect, developed the concept of "life between buildings" in order to embrace the entire spectrum of activities that combine communal spaces in cities and residential areas in meaningful and attractive ways (Gehl 1971). Gehl underpinned the idea that social activities in an urban design perspective could be characterised as encompassing "all activities that depend on the presence of others in public spaces" (Gehl 1971 p.10). According to Gehl, social activities occur spontaneously as a direct consequence of people moving about and being in the same spaces:

'Social activities include children at play, greetings and conversations, communal activities of various kinds, and finally - as the most widespread social activity - passive contacts, that is simply seeing and hearing other people'. (Gehl 1971, p.10; see also Carmona and Tiesdell 2007).

With this definition of social activities, Gehl points out the fundamental importance of urban planning in framing the possibility for social life activities to take place.

Ray Oldenburg (1999), the American sociologist, argues in his book The Great Good Place that "third places" - informal public gathering places, where people can gather outside work and home in inclusively sociable places - are essential for a functioning civil society, democracy and civic engagement. Meeting places, where the concerns of work and home are put aside and people gather simply for the pleasure of good company and lively conversation, are the heart of a community's social vitality and the grassroots of democracy. He emphasises the importance of places 
where individuals feel at home and comfortable and where they may come and go as they please. Oldenburg pointed out that without neutral ground in the neighbourhoods where people live, association outside the home will be impoverished:

'Neighbours will never associate, if there is no place for them to do so. The third place may be a solution in reframing the way interpersonal interaction is approached on an individual level'. (Oldenburg 1999, p.88).

In urban planning, architecture and design, we often find that framing possibilities for older people to gain access to urban space is absent from the agenda. But social life in a third-place perspective is important for older residents of nursing home. Access to association on neutral ground in the neighbourhood outside the institution can be very important for nursing home residents whose everyday life is institutionalised. The importance of access to a social life does not disappear as one gets older, even though the need may change character with increasing age. As a researcher on ageing, Sari Rissanen (2013) established that access to a social life is just as important for older persons' quality of life as good physical health. This applies regardless of whether people live in their own domestic home or in a nursing home (Rissanen 2013).

Despite the fact that urban planning debates engage with the need to respond to demographic change, the focus is primarily on where to place older persons and less on enabling older persons, as citizens with the right to a social life, to participate in practice in city life in their neighbourhood and in the local community. Buffel et al. (2019) emphasise:

'the need for a stronger embedding of the age-friendly mission in a citizenship- and rightsbased narrative of ageing, one that is centred on values of equality, community empowerment and spatial justice'. (p.288).

In general, this type of approach may be especially challenging for nursing home residents.

\subsection{Social Inclusion in Indoor and Outdoor Environments in a Capability Perspective}

The capability approach, a moral-philosophical theoretical framework concerning well-being, development and justice, has been pioneered by the economistphilosopher Amartya Sen and further developed by the philosopher Martha Nussbaum. The concept entails two core normative claims: first, the claim that the freedom to achieve well-being is primarily of moral importance; and second, that the freedom to achieve well-being is to be understood in terms of people's capabilities, which refers to individuals' real opportunities to do and be what they have reason to value (The Stanford Encyclopedia of Philosophy 2016). In Nussbaum's perspective, the key focus is on the freedom to achieve well-being as a matter of what people are able to do and to be, and thus the kind of life they are able to live in practice: 
'What is each person able to do and to be? It is focused on choice or freedom, holding that what the crucial good societies should be promoting for their people is a set of opportunities, or substantial freedoms, which people may or may not exercise in action: the choice is theirs'. (Nussbaum 2011, p.18).

The capability concept contains the central values of the WHO Healthy Ageing definition, which includes participation, justice, autonomy and safety (Hörder 2016). In this perspective there is a political obligation to frame capability for everybody (Nussbaum 2011), with respect for the notion that everyone should have the human freedom to live a life they have reason to value (Sen 1982). With reference to the potential vulnerability of some older persons (Katz 2010), a core feature of the capability perspective is not to normalise social exclusion of older individuals, but to provide a basis for their social inclusion in the way they value being included, however vulnerable they might be (Wiles and Jayansinha 2013).

Against this background, an important question concerns how nursing home architecture can make it possible for residents living in a nursing home to participate in urban life and be part of the social activities that they value.

\subsection{The Historical Context}

Often called "old people's homes", in earlier times, nursing homes were typically placed in quiet areas removed from city life, where the residents often had only a small bedroom and a shared bathroom and ate their meals in a communal dining hall. Compared to the general housing standard in Denmark, this nursing home standard gradually came to be seen in the policy and planning discourse of the 1980s as out-dated. In accordance with legislation introduced in 1987 (the Social Housing Act [Almenboligloven 2019]), most nursing homes in Denmark are now organised as general social housing for older persons with associated care and service functions. This means that (unlike in former "old people's homes") residents have individual leases and pay rent and other expenses for their own homes and shared facilities. They also have democratic rights regarding the running of the nursing home. Besides having their own individual homes, with a bedroom, small living room, kitchenette and bathroom, residents share dining and living facilities and have access to public facilities like cafés, physical training gyms, music activities and such together with other, mostly older people, living in the same residential neighbourhood. Depending on their abilities, both residents in the nursing home and residents in the surrounding residential areas have the option of meeting, interacting and enjoying social activities together.

Compared to the former institutionalised nursing homes, modern nursing homes are similar to ordinary housing, with private and common facilities but with additional care for residents in need. 


\subsection{New Knowledge About How to Protect Vulnerable Residents Through Nursing Home Design}

Recent reviews of relevant national and international research compiled in a national guideline for Danish nursing homes show that design of the physical environment is of great importance for older persons' well-being and quality of life. It is important to be able to stay connected to the local area you live in and to continue to feel part of a community. The guidelines of the Department of the Built Environment (the former Danish National Building Research Institute) (Sigbrand et al. 2019) argue that a nursing home should provide easy access to the surrounding local society, both for residents and their visiting relatives.

Compared to the situation in the 1980s and 1990s, the profile of nursing home residents has changed significantly. Today, since the majority of nursing home residents can be classified as "frail", they are mainly dependent on living in a supportive environment (The Ministry of Health 2017). Under these circumstances, it is expected that nursing homes should have a homely atmosphere, good access to daylight, and close contact to nature, both visually and directly in a secure outdoor area. If these elements exist in a nursing home, the quality of life of residents, judged to be vulnerable, may improve and medication be reduced or avoided altogether (Sigbrand et al. 2019; Siren et al. 2019).

\subsection{Four Nursing Home Concepts and Spatial Inclusion}

Based on pioneering examples of nursing home planning principles that aim to integrate the surrounding local community and to facilitate social inclusion of nursing home residents, we now proceed to present four distinct contemporary cases from The Netherlands and Denmark. The criteria for the case selection draw on principles of "strategic exemplarity" (Flyvbjerg and Sampson 2001). In this sense, the aim is to illustrate how new trends in architecture and urban policy can support nursing home residents to become part of local city and social life. The cases have been chosen with reference to innovation of existing approaches in the field or a "best case" criterion, i.e. projects that demonstrate political and public awareness (e.g. at local government level) and innovative professional commitment and visibility (by architects, planners and nursing home professionals) to overcome or reduce the risks of social exclusion faced by nursing home residents.

The first case is the Closed Village: the de Davidoff nursing home in Amsterdam (https://hogeweyk.dementiavillage.com/). This project was completed in 2009 and is designed as a closed village for older people living with severe forms of dementia. The Hogeweyk project consists of 23 houses and is home to 152 residents. In spite of their cognitive impairment, residents are enabled to live a normal life with freedom in safety. All buildings are closed to the surrounding neighbourhood, and only 
one gate opens to the outside world. This ensures that residents can safely roam freely in the streets and park without getting lost. A restaurant, theatre, supermarket, hair salon and different activity rooms can be used by residents and visiting relatives. The nursing home is situated in a residential area and residents from the local neighbourhood are invited inside to use the different facilities and to stroll in the streets and park. In this way, residents can remain connected to society outside the nursing home.

The second case is the Intergenerational Neighbourhood: the planned nursing home Ingeborggaarden (https://www.frederiksberg.dk/sites/default/files/meetingsappendices/53F4AEA9-BC1D-40E0-91B7-F6F8669BA271/2535700-2694951-1. $\mathrm{PDF}$ ) is located in Frederiksberg Municipality in the Copenhagen Region. The political context here was that the City Council was inspired by the WHO programme, Global Age-Friendly Cities (WHO 2018). A local left-wing politician, Thyge Enevoldsen, had placed the political focus for more than 20 years on the importance of framing rights and quality of life for Frederiksberg's nursing home residents. It is a nursing home that is planned to have a close relationship with the neighbourhood i.e. with the local football club through common areas, both inside and outside the building, that frame intergenerational meeting places and meetings between younger and older community residents. Nursing home residents have the possibility to watch the young football players, meet them in the cafés, interact with them and maybe even help them with homework. The nursing home is about to be constructed in an urban residential area and is expected to be completed in 2023. It will accommodate approximately 200 residents with either cognitive impairment or physical disabilities, living in housing groups comprising 10-13 individual homes with shared living rooms, dining rooms and balconies. The overall approach of the nursing home is openness towards the neighbourhood, with communal facilities on the ground floor and a city park. The plan is to take care of the special needs of residents with severe dementia in a common, sheltered day centre connected to a secret garden, located at the heart of the building away from noisy activities. The plan also envisages that, depending on their wishes and needs, all residents will be able to follow and participate in activities connected to the local football club and wider neighbourhood.

The third case is New Soelund (http://www.detnyesoelund.dk/) in Copenhagen, which we call Age-Friendly Urbanism: The Danish social housing association, $\mathrm{KAB}$, is building a new nursing home close to one of the city's most attractive and lively neighbourhoods, Noerrebro. New Soelund will replace an existing, outdated nursing home in a central, densely-populated residential area. It will become the largest nursing home in Copenhagen, with 360 residents living on a daily basis in smaller housing groups of 8-12 people who share dining and living areas, cohousing for 20 senior citizens, 150 housing units for young people, a day-care centre for approximately 75 children, and roof gardens for school pupils from the surrounding neighbourhood. Moreover, New Soelund will provide the neighbourhood with small shops and other facilities. New Soelund is expected to be ready to welcome its first residents in late 2022. This particular case provides an example of how municipalities and non-profit social housing associations have started to work 
with the idea of age-friendly urbanism in order to facilitate generational integration and avoid spatial exclusion of nursing home residents from the local neighbourhood. The nursing home is placed on a relatively quiet site close to one of the lakes in Copenhagen, where there are pedestrian and cycle paths, so that pedestrians and cyclists pass by during the daytime and evening hours. A town square for generations, with benches and cafés, makes New Soelund attractive for people who pass by to take a break, thereby enabling contact between residents and non-residents. At the same time, the aim is to use the nursing home as an urban frame for social activities, and to provide a context within which residents can experience urban life, fresh air, and contact with passers-by and also with young people on their way to and from school.

The final case is Dagmarsminde in Graested, which we call the Caring Countryside Oasis, was opened in 2016 in the countryside north of Copenhagen (http://dagmarsminde.dk/). Dagmarsminde is a small nursing home with 10 separate units for 11 residents, all with severe dementia. The residents have their own individual bedrooms and bathrooms. They live in a very homely environment, sharing living and dining areas, a conservatory, library and a wellness and sensory room. The building is surrounded by a large fenced garden with a henhouse, rabbits and an enclosure with goats, which is situated next to fields and a forest. The building is a remodelled carpentry workshop. The nursing home is described as a caring oasis, and, compared to other large nursing homes, Dagmarsminde could be regarded as a pioneer case when it comes to the scale of the nursing home and the approach to the care of residents. Close contact to nature and animals, access to daylight, and a high degree of homeliness are central elements of the care provided, which focuses on supporting residents' well-being and quality of life with less medication. Depending on the abilities and needs of individual residents, care staff take trips, for example to the beach or forest. Family members are an important part of daily life and activities even though there is a fairly long distance to a city, and young children in the neighbourhood or grandchildren come to do their homework at the dining table, as they do in an ordinary home. By taking tours and inviting people in to take part in their daily life, residents maintain their connections with the social life of the community beyond the nursing home.

Residents with severe dementia are often sensitive to excessive stimulation, whether from being surrounded by many people or by engaging with the noisy and hectic activity of city life. However, visual contact, such as seeing and hearing other people is important: "Enjoying a view, listening to music, or simply watching other people's activities, visitors or staff, can be engaging activities" (Scheel Thomasen 2013 p.112). Close contact with nature, broadly understood, is another important factor for such residents with such sensitivities in order that they can feel at ease and comfortable. Easy access to nature is important in providing sensory stimulation (Clancy 2016) and is the focus of the Dagmarsminde nursing home. 


\subsection{Discussion}

Drawing the threads of this chapter together, it is evidently important to focus on capability when creating opportunity structures through planning and designing nursing homes for the future, both with regards to residents with and without dementia. However, there is not only one simple response to the question about how architecture and urban policy approaches can frame spatial inclusion for nursing home residents. The four illustrative cases highlight different approaches to creating possibilities for facilitating social inclusion of older nursing home residents in the surrounding neighbourhood and local society.

For Dagmarsminde, the radical answer was to "go back to nature" and to locate the nursing home with easy access to nature and to use actively the natural facilities in the daily practices of care work and social activities. Dagmarsminde, from a capability perspective, functions well by supporting life quality in such a way that the residents have opportunities to participate in social activities according to their own individual conditions, without being obliged to engage in activities that may cause them undue stress.

As for the Hogeweyk project, the scheme has aimed to provide opportunities for the residents with severe dementia to roam safely and freely in a "city-like" environment within the area of the nursing home. From a capability perspective, the result is that residents can join a "city-like" social practice in a safe way, but without accessing the surrounding neighbourhood. De Hoogeweyk provides a quiet city area for the local neighbourhood, with non-residents invited inside to use the different facilities alongside residents and to stroll in the streets and park, offering an alternative to the noisy city-life outside.

From Ray Oldenburg's "third-place perspective", both Ingeborggaarden and New Soelund are planned in ways that contribute to age-friendly urbanism with emphasis on informal public gathering places, where people can congregate outside work and home in inclusive, sociable places. These housing schemes can frame the social life of residents by providing opportunities on a daily basis to connect with citizens outside the nursing home.

The Ingeborggaarden nursing home, situated in a quiet part of Frederiksberg Municipality, aims to foster intergenerational interaction in everyday life and to avoid age segregation. It combines indoor facilities for residents, including providing possibilities for peacefulness for residents with severe dementia in the "secret garden", with age-friendly outdoor surroundings and facilities, in order to share facilities with the local community for residents who want to be part of social life in the neighbourhood. Ingeborggaarden is a key part of the municipality's plan to be "the city of generations". Communal areas and facilities like a café are connected to the nursing home. The scheme offers the younger generation of football players the possibility to have daily contact with the older generation. Informal conversations and help with homework can support and sustain important relationships between generations. 
With New Soelund positioned in an attractive location, close to the city of Copenhagen's lakes and its well-used pedestrian and cycle paths, residents will have direct access to a vibrant metropolitan life. The residents will become an integrated part of the urban neighbourhood with opportunities for direct contact with younger generations in the shared areas. New Soelund represents an innovative contribution to urban social life by inviting local residents, bypassing pedestrians and cyclists, to use the place in front of the nursing home together with the nursing home residents. That said, there are also challenges associated with this development. In particular, the residents who formerly lived in the old Soelund were moved away long before the building process started. Former residents felt it was unjust that they had to leave their home by the lakes. Since they and their neighbours felt that their views were not taken into account in the planning process, it will be important to follow and evaluate the development and impact of the nursing home in the years to come.

With regard to the capability perspective, it is important to investigate whether residents of Ingeborggaarden will indeed become part of the social life of the neighbourhood that surrounds the nursing home in the way that they and their relatives value. It is not clear whether residents will be able to gain access to the surrounding green area if they want to or whether they will be able to navigate the physical environment with a walker or wheelchair, so that the nursing home component of the intergenerational city life will come to fruition as planned. It also remains unclear how social contact between the football players and residents and their relatives will occur.

\subsection{Conclusion}

The four examples we have described are valuable examples of innovation in nursing home planning and design principles. The cases support, in different ways, the residents' capability to be part of social activities in city life in the way they value showing respect for individualism and regarding residents as a heterogeneous group with different needs, values and capabilities. From a capability perspective, it is inevitable that residents, relatives, care-workers and neighbours should in future be empowered as important stakeholders in the evaluation as well as in the planning of new nursing homes. This can open up new knowledge about the connection between nursing home locations, design and improved spatial inclusion of nursing home residents (Rissanen 2013, McDonald et al. 2019). In particular, it is important not to forget that nursing home residents, including those who are experiencing cognitive decline, are able to express their wishes and values, if asked. 


\section{Editors' Postscript}

Please note, like other contributions to this book, this chapter was written before the COVID-19 pandemic of 2020. The book's introductory chapter (Chap. 1) and conclusion (Chap. 34) consider some of the key ways in which the pandemic relates to issues concerning social exclusion and ageing.

\section{References}

Almenboligloven. (2019). https://www.retsinformation.dk/pdfPrint.aspx?id=206725

Barry, B. (2002). Social exclusion, social isolation and the distribution of income. In J. Hills, J. Le Grand, \& D. Piachaud (Eds.), Understanding social exclusion (pp. 13-29). Oxford: Oxford University Press.

Buffel, T., Handler, S., \& Philipson, C. (2019). Age-friendly cities and communities: a manifesto for change. In T. Buffel, S. Handler, \& C. Philipson (Eds.), Age-friendly cities and communities: A global perspective. Bristol: Policy Press.

Carmona, M., \& Tiesdell, S. (2007). Urban design reader. New York: Architectural Press/ Routledge.

Clancy, A. (2016). Steder rommer elementene. Det nordlige mennesket og stedets betydning for helse og velbefinnende. In Stenbock-Hult, B. \& Sarvimäki, A. (Eds.), Healthy ageing. Nordiske perspektiv på äldres hälsa och främjande av äldres hälsa (Arcada Working Papers 2/2016).

Dagmarsminde. http://dagmarsminde.dk/. Accessed 30 Mar 2020.

Davidoff, P. (1965). Advocacy and pluralism in planning. Journal of the American Institute of Planners, 31(4), 331-338.

De Hogeweyk.: https://hogeweyk.dementiavillage.com/en/kenniscentrum/

Flyvbjerg, B., \& Sampson, S. (2001). Making social science matter-why social inquiry fails and how it can succeed again. Cambridge: Cambridge University Press.

Gehl, J. (1971). Life between buildings: Using public space. Skive: Arkitektens Forlag.

Healy, P. (2003). Collaborative planning in perspective. Planning Theory, 2(2), 101-123. Sage Publications.

Hörder, H. (2016). En kapabilitietsansats till Healthy Ageing. In B. Stenbock-Hult \& A. Sarvimäki (Eds.), Healthy Ageing. Nordiske perspektiv på äldres hälsa och främjande av äldres hälsa (Arcada Working Papers 2/2016).

Ingeborggården. https://www.frederiksberg.dk/sites/default/files/meetings-appendices/53F4AEA 9-BC1D-40E0-91B7-F6F8669BA271/2535700-2694951-1.PDF. Accessed 30 Mar 2020.

Jacobs, J. (1961). The death and life of great American cities. London: Jonathan Cape.

Katz, S. (2010). Sociocultural perspectives on ageing bodies. In D. Dannefer \& C. Phillipson (Eds.), The Sage handbook of social gerontology (pp. 357-366). Los Angeles/London/New Delhi/Singapore/Washington: Sage.

Macleod, C., et al. (2017). Re-thinking social exclusion in later life: A case for a new framework for measurement. Ageing \& Society, 39, 74. Cambridge University Press.

Marcuse, P. (2011). The three Historic currents of City Planning. In G. Bridge \& S. Watson (Eds.), The new Blackwell companion to the city. Oxford: Blackwell Publishing.

McDonald, B., Scharf, T., \& Walsh, K. (2019). Creating an age-friendly county in Ireland: Stakeholders' perspectives on implementation. In T. Buffel, S. Handler, \& C. Philipson (Eds.), Age-friendly cities and communities a global perspective. Bristol: Policy Press.

Ministry of Health (Sundheds- og Aeldreministeriet). (2016) National unders $\phi$ gelse af forholdene på plejecentre. https://sum.dk/ /media/Filer\%20-\%20Publikationer_i_pdf/2016/Nationalundersoegelse-af-forholdene-paa-plejec/Undersoegelse-af-forholdene-paa-plejecentre.pdf 
The Ministry of Health (Sundheds- og Aeldreministeriet). (2017): Plejecentre.https://www.sum. $\mathrm{dk} /$ Aeldre/Boliger-til-aeldre/Plejecentre.aspx

Moulaert, T., Wanka A., \& Drilling M. (2018). The social production of age, space and exclusion. Social Studies 1.

Nussbaum, M. (2011). The human development approach. In M. Nussbaum (Ed.), Creating capabilities. Cambridge, MA: Belknap Press of Harvard.

Oldenburg, R. (1999). The Character of Third Places. In R. Oldenburg (Ed.), The Great Good Place: Cafés, coffee shops, bookstores, bars, hair salons and the other great hangouts at the heart of a community (2nd ed., pp. 2-42). New York: Marlowe \& Company. (First edition published in 1989).

Philips, J., Ajrouch, K.J., \& Hillcoat-Nalletamby, S. (2010). Key concepts in social gerontology (Sage Key Concepts). London: Sage.

Rissanen, S. (2013). Wellbeing and environment, concepts in the elderly care home context. In A. Hujala, S. Rissanen, \& S. Vihma (Eds.), Designing wellbeing in elderly care homes (Aalto University publication series Crossover 2.13) (pp. 20-35).

Scheel Thomasen, L. (2013). A good old age? Life as a nursing home resident in Denmark. In A. Hujala, S. Rissanen, \& S. Vihma (Eds.), Designing wellbeing in elderly care homes (Aalto University, Crossover, 2.13) (pp. 102-114).

Sen, A. (1982). Choice, welfare and measurement. Oxford: Basil Blackwell.

Sigbrand, L., Bredmose, A., Jensen, P. H., Kirkeby, I. M., Lygum, V. L., \& Mathiasen, N. (2019). Plejeboliger for personer med demens - detaljer og eksempler (Nursing homes for people with dementia- Details and examples) Institute of the Built Environment (The Danish building research institute), Aalborg University, Copenhagen.

Siren, A., Grønfeldt, S. T., Andreasen, A. G., \& Bukhave, F. S. (2019). Sociale mursten: En forskningskortlagning af fysiske rammers betydning $i$ velfardsindsatser. Copenhagen: VIVEViden til Velfærd Det Nationale Forsknings- og Analysecenter for Velfærd.

Soelund. http://www.detnyesoelund.dk/. Accessed 30 Mar 2020.

The Stanford Encyclopedia of Philosophy. (2016) Plato. Stanford.edu.

Vidovićová, L., \& Tournier, L. (2020). Community and spatial aspects of exclusion in later life. In K. Walsh \& T. Scharf (Eds.), Reducing old-age exclusion: Collaborations in research and policy (ROSEnet briefing paper series: No. 2. CA 15122). ISBN: 978-1-908358-72-1.

Walker, A. (2010). Ageing and quality of life in Europe. In D. Dannefer \& C. Phillipson (Eds.), The Sage Handbook of Social Gerontology. London: Sage.

Wiles, J. (2005). Conceptualizing place in the care of older people: The contribution of geographical gerontology. International Journal of Older People Nursing in association with Journal of Clinical Nursing, 14, 100-108.

Wiles, J., \& Jayansinha, R. (2013). Care for place: The contributions older people make to their communities. Journal of Aging Studies, 27, 93-101. Elsevier.

World Health Organization. (2018). What is healthy Ageing?. www.who.int/ageing/healthy-ageing/en/. Accessed 10 Oct 2019. 
Open Access This chapter is licensed under the terms of the Creative Commons Attribution 4.0 International License (http://creativecommons.org/licenses/by/4.0/), which permits use, sharing, adaptation, distribution and reproduction in any medium or format, as long as you give appropriate credit to the original author(s) and the source, provide a link to the Creative Commons license and indicate if changes were made.

The images or other third party material in this chapter are included in the chapter's Creative Commons license, unless indicated otherwise in a credit line to the material. If material is not included in the chapter's Creative Commons license and your intended use is not permitted by statutory regulation or exceeds the permitted use, you will need to obtain permission directly from the copyright holder. 